\title{
The Psychological Well-Being among Left-Behind Children of Labor Migrant Parents in Rural Northern Vietnam
}

\author{
Nguyen Van Luot, Nguyen Ba Dat \\ Faculty of Psychology, University of Social Sciences and Humanities, Vietnam National University (VNU-Hanoi), \\ Hanoi, Vietnam \\ Email: luotnv@vnu.edu.vn, datnb@ussh.edu.vn
}

How to cite this paper: Luot, N.V. and Dat, N.B. (2017) The Psychological WellBeing among Left-Behind Children of Labor Migrant Parents in Rural Northern Vietnam. Open Journal of Social Sciences, 5, 188-201.

https://doi.org/10.4236/jss.2017.56017

Received: May 10, 2017

Accepted: June 17, 2017

Published: June 20, 2017

Copyright $\odot 2017$ by authors and Scientific Research Publishing Inc. This work is licensed under the Creative Commons Attribution International License (CC BY 4.0).

http://creativecommons.org/licenses/by/4.0/

(c) (i) Open Access

\section{Abstract}

Background: In Asia, especially in China and ASEAN, it has been an obvious trend that the population in general and parents in particular leave the countryside to bigger cities or more developed countries for employment opportunities. Many migrant workers are forced to leave their children at home with caregivers, particularly in families with both husband and wife working away from home. Studies worldwide have showed that, besides positive economic and social impacts, labor migrant parents also cause negative effects to the well-being of those they leave behind, especially children. However, this study orientation has not generated significant interest in Vietnam. Participants: This paper indicates the results of a survey on 469 left-behind children of labor migrant parents in rural areas by comparing them with a control group of 650 children living with their parents in three rural areas of North Vietnam including Phu Tho, Bac Ninh and Ha Nam provinces. Besides, we also survey 363 caregivers (parent or grandfather/grandmother of left-behind children) about psychological well-being of left-behind children. Method: Strengths and Difficulties Questionnaire (SDQ) was used for this study. SDQ was Vietnamized by author Dang Hoang Minh et al. (2013) and adaptable to Vietnamese teenagers. Results: As reported by the surveyed children, the SDQ mean total difficulties score of those having migrant parents was 12.55 $(\mathrm{SD}=5.96)$ and $18.9 \%$ of these children had scores higher than the cut-off score. As rated by caregivers, they were $11.12(\mathrm{SD}=5.14)$ and $15.1 \%$, respectively. There is a statistically significant difference in mental health between the LBC and non-LBC group. The general trend is that the LBC reported to have higher scores of total difficulties and specific expressions including hyperactivity/inattention, emotional symptoms, peer relationship problems, conduct problems than that of non-LBC. Self-esteem and self-assessment of 
academic performance is the key factors affecting total difficulties of left-behind children.

\section{Keywords}

Psychological Well-Being/Mental Health, "Left behind Children", Migrant Parents

\section{Introduction}

Studies worldwide indicate that parents working away from home have negative impacts on their left-behind children in many aspects. Studies by Zhao, Yu, Wang \& Glauben (2014) show that parental migration for employment has negative influences on children's learning, for example, their academic performance is reduced [1], or their learning process is interrupted as found by Zhaobao Jia \& Tian (2010) [2], or children find difficulty in communicating with their teachers and friends in studies by Luo, Gao \& Zhang (2011) [3]. Rural children having absent parents have more negative emotions than those living with parents as indicated in studies of Z. Jia \& W. Tian, 2010; Jingzhong \& Lu (2011). They feel lonely and bored [2] [4]. Children with absent parents also show their worry, insecurity and fear in studies of Fan, Su \& Gill (2010) [5]. Moreover, children of migrant parents also have trouble in self-assessment, for example, they are un-self-confident, aloof and isolated in studies of Jingzhong \& $\mathrm{Lu}$ (2011); Shen \& Shen (2014) [4] [6]. They also have low self-assessment according to studies of Xiajun (2015) [7]. Wen \& Lin, (2012) found that children of migrant parents were less satisfied with their life and learning than those of non-migrant parents, especially children whose mothers worked away [8]. According to studies of Fan et al., parental migration due to employment does not only cause negative impacts on children's learning, emotions and self-assessment, but also creates negative behaviors on left-behind children. These studies also show that boys tend to display their negative behaviours higher than girls [5] [8].

In Vietnam, it has been an obvious trend that the population in general and parents in particular leave the countryside to bigger cities or more developed countries for employment opportunities. According to the General Statistics Office, in 2015, the number of domestic migrants aged 15 years-old and over was approximately 1.24 million people in which women accounted for $57.7 \%$, and up to $78.4 \%$ of them participated in the workforce (the remaining $21.6 \%$ are students or unemployed). The majority of these people move to urban areas. Furthermore, by the end of 2015, around 500,000 people in Vietnam were engaged in labor export to different 40 countries and territories [9]. Many migrant workers are forced to leave their children at home with caregivers, particularly in some families, both husband and wife work away from home. According to Hoang Ba Thinh, Nicola Piper, Vu Ngoc Binh (2012), parental migration can 
provide positive socio-economic impacts, especially in terms of financial support which helps maintain living and learning conditions of their children at home [10] [11] [12].

It can be noted that studies on left-behind people including children and the elderly have been less thorough in Vietnam. According to our literature review, there are a few studies on the impact of working migrant parents to children left-behind. Graham et al. 2011 carried out a survey with 3876 children (aged 3 12) on well-being of children in four Southeast Asian countries (including Vietnam) based on opinions of caregivers. However, this study showed that in Vietnam, there was no difference in well-being between children whose parents work away from home and those living with their parents [13]. Using data from the Young Lives survey in 2007 and 2009 with 7725 children aged 5 - 8 in 4 countries Ethiopia, India, Peru and Vietnam, author Nguyen Viet Cuong supposed that migrant parents helped improve the financial situation of their families, but did not increase their children's health and cognitive abilities. Parents working away from home were the cause of health and cognitive problems in children in Vietnam as well as in Peru and India. Children who suffered from long-term parental migration tended to be affected more negatively than those with short-term migrant parents. The lack of communication between parents and children as well as parental care was the leading cause of nutrition and learning problems in children [14].

Thus, we can see that there have been very few studies on negative impacts of parental migration to left-behind children through the self-assessment of these children. This is definitely a research gap in Vietnam. The purpose of this article is to answer the following questions: 1) how is the current state of the psychological well-being of children whose parents work away from home?; 2) what is the difference in the psychological well-being among groups of children of migrant parents?; and, 3) which individual and family factors could anticipate the left behind children's total difficulties?

\section{Methods}

\subsection{Participants}

This study involves quantitative cross-sectional research. Samples were selected by simple random sampling method. Total number of surveyed samples include 1119 children aged 9 to 15 (469 children of migrant parents, 650 children of non-migrant parents) and 373 caregivers (132 male and 203 female). The survey was carried out in three sites in northern Vietnam, specifically in Lam Thao district, Phu Tho province; Gia Binh district, Bac Ninh province and Ly Nhan district, Ha Nam province. The site selection is based on the fact that the ratio of local people working away from home in these sites is higher than that of other regions in the north of Vietnam. The questioned children were studying from grade 4 to grade 9 at primary and secondary schools. The study samples are described in detail in Table 1. 
Table 1. Description of surveyed samples.

\begin{tabular}{|c|c|c|c|c|}
\hline Criteria & Classification & $\begin{array}{c}\text { LBC } \\
(\mathrm{N}=469)\end{array}$ & $\begin{array}{l}\text { Non-LBC } \\
(\mathrm{N}=650)\end{array}$ & $\begin{array}{c}\text { Caregivers } \\
(\mathrm{N}=363)\end{array}$ \\
\hline \multirow{2}{*}{ 1. Sex } & Male & $50.1 \%(\mathrm{n}=235)$ & $47.1 \%(\mathrm{n}=306)$ & $39.4 \%(\mathrm{n}=132)$ \\
\hline & Female & $49.9 \%(\mathrm{n}=234)$ & $52.9 \%(\mathrm{n}=344)$ & $60.6 \%(n=203)$ \\
\hline \multirow{2}{*}{ 2. Age } & Aged $9-11$ & $48.6 \%(\mathrm{n}=227)$ & $48.8 \%(\mathrm{n}=312)$ & - \\
\hline & Aged $12-15$ & $51.4 \%(\mathrm{n}=240)$ & $51.6 \%(\mathrm{n}=333)$ & - \\
\hline \multicolumn{2}{|c|}{ Mean (SD) } & $11.70(1.59)$ & $12.01(1.68)$ & $56.60(14.54)$ \\
\hline \multirow{2}{*}{ 3. Level of school } & Primary school & $49.3 \%(\mathrm{n}=231)$ & $51.7 \%(\mathrm{n}=336)$ & - \\
\hline & Secondary school & $50.7 \%(\mathrm{n}=238)$ & $48.3 \%(\mathrm{n}=314)$ & - \\
\hline \multirow{3}{*}{$\begin{array}{l}\text { 4. Length of } \\
\text { parental } \\
\text { migration }\end{array}$} & $\leq 2$ years & $39.0 \%(\mathrm{n}=139)$ & - & - \\
\hline & $2-5$ years & $33.4 \%(\mathrm{n}=119)$ & - & - \\
\hline & $>5$ years & $27.5 \%(\mathrm{n}=98)$ & - & - \\
\hline \multicolumn{2}{|c|}{ Mean (SD) } & $4.24(3.90)$ & - & - \\
\hline \multirow{4}{*}{$\begin{array}{l}\text { 5. Who works } \\
\text { far away } \\
\text { from home }\end{array}$} & Father & $39.4 \%(\mathrm{n}=176)$ & - & - \\
\hline & Mother & $23.5 \%(\mathrm{n}=105)$ & - & - \\
\hline & Two parents & $37.1 \%(\mathrm{n}=166)$ & - & - \\
\hline & Phu Tho & $23.9 \%(n=112)$ & $123.4 \%(n=152)$ & $22.6 \%(\mathrm{n}=82)$ \\
\hline \multirow[t]{2}{*}{$\begin{array}{l}\text { 6. Residential } \\
\text { area of children }\end{array}$} & Bac Ninh & $32.8 \%(\mathrm{n}=154)$ & $34.2 \%(\mathrm{n}=222)$ & $28.7 \%(\mathrm{n}=104)$ \\
\hline & Ha Nam & $43.3 \%(n=203)$ & $42.5 \%(\mathrm{n}=276)$ & $48.8 \%(n=177)$ \\
\hline \multirow[t]{4}{*}{$\begin{array}{l}\text { 7. Relationship } \\
\text { with LBC }\end{array}$} & Mother of LBC & & & $22.6 \%(\mathrm{n}=80)$ \\
\hline & Father of LBC & - & - & $12.4 \%(\mathrm{n}=45)$ \\
\hline & Grandmother/father & - & - & $61.0 \%(n=216)$ \\
\hline & Relatives & - & - & $3.7 \%(\mathrm{n}=13)$ \\
\hline \multirow[t]{2}{*}{$\begin{array}{l}\text { 8. Have trouble } \\
\text { with their health }\end{array}$} & Yes & - & - & $37.8 \%(\mathrm{n}=128)$ \\
\hline & No & - & - & $58.1 \%(\mathrm{n}=211)$ \\
\hline
\end{tabular}

Note: LBC-Left-behind children; Non-LBC-Non-Left behind children.

\subsection{Materials}

In this study we used the Strengths and Difficulties Questionnaire (SDQ) for three groups of children including children having parents working far away from home, children living with parents and caregivers of left-behind children. The questionnaire consists of 25 items including 10 items on strength, 14 items on weakness, and one neutral item. Three answer options are available for each item, 0 -not true; 1 -somewhat true; 2 -certainly true. The questionnaire is divided into 5 scales, five questions per scale which are hyperactivity/inattention, emotional symptoms, conduct problems, peer relationship problems, and prosocial behaviour. The scale of prosocial behaviour is positive. The remaining four scales are negative, which are added together to score the total difficulties score. 
The SDQ questionnaire used in this study is based on the Vietnamese version that has been made adaptable and used by Dang Hoang Minh et al. (2013) [15].

\subsection{Research Process}

First, we contacted and received the consent of selected schools' managing boards and homeroom teachers to carry out the survey with their students. Then, within each grade, the researchers chose one group of children whose parents work away from home, and another group of children living with their parents in order to conduct the survey. Each student was received a survey sheet/questionnaires and completed it on their own. The students and caregivers gathered at a meeting hall of each school under the guidance of the research team's members.

\subsection{Processing Techniques}

All the data was processed by a Statistical Package for the Social Sciences (SPSS version 20.0).

\section{Results}

\subsection{Overview on Psychological Well-Being of Children}

Table 2 shows that $17.4 \%$ and $1.5 \%$ of the total difficulties score of self-reported children having parents working far from home are in the borderline and abnormal band, respectively. The total percentage of these two scoring bands is $18.9 \%$. For children living with parents, $16.5 \%$ of this group score in the borderline band and $1.8 \%$ in the abnormal band, thus, the total is $18.3 \%$. However, as reported by caregivers, the total percentage of the aforementioned two scoring bands is lower with only $15.1 \%$.

As reported by LBC, the proportion of children with hyperactivity/inattention problems was the highest with $12.1 \%$ and $1.3 \%$, respectively, scoring in the borderline and abnormal band (the total of these two scoring bands was $13.4 \%$ ). The next was children with emotional problems with $7.2 \%$ placed in borderline banding and $8.6 \%$ in abnormal banding, the total was $15.8 \%$. As reported by caregivers, the percentage of LBC having emotional problems was the highest with $7.0 \%$ and $13.4 \%$ scoring in borderline and abnormal band, respectively $(20.4 \%$ in total) and followed by those having peer problems with $12.7 \%$ and $3.3 \%$ (16\% for both scoring bands).

\subsection{Comparison of SDQ Score between LBC and Non-LBC}

One of research questions raised by the survey team is that whether children of parents working away from home have to encounter more psychological well-being problems than those living with parents or not? The results are revealed in Table 3.

Overall, the total difficulties score of LBC is higher than that of non-LBC, 12.55 of mean score when compared with 10.17 of children living with parents. 
Table 2. Percentage of children groups' mental health.

\begin{tabular}{|c|c|c|c|c|c|}
\hline \multirow{2}{*}{ Contents } & \multirow{2}{*}{ Groups of children } & \multirow{2}{*}{ Mean (SD) } & \multicolumn{3}{|c|}{ Percentage } \\
\hline & & & Normal & Borderline & Abnormal \\
\hline \multirow{3}{*}{$\begin{array}{l}\text { Hyperactivity } \\
\qquad(0-10)\end{array}$} & $\mathrm{LBC}(\mathrm{N}=447)$ & $3.31(1.94)$ & $86.6 \%$ & $12.1 \%$ & $1.3 \%$ \\
\hline & Non-LBC $(\mathrm{N}=610)$ & $2.56(1.11)$ & $80.3 \%$ & $15.4 \%$ & $4.3 \%$ \\
\hline & Caregivers $(\mathrm{N}=336)$ & $3.17(1.94)$ & $87.5 \%$ & $9.8 \%$ & $2.7 \%$ \\
\hline \multirow{3}{*}{$\begin{array}{c}\text { Emotional } \\
\text { Problems } \\
(0-10)\end{array}$} & $\mathrm{LBC}(\mathrm{N}=443)$ & $3.93(2.40)$ & $84.2 \%$ & $7.2 \%$ & $8.6 \%$ \\
\hline & Non-LBC $(\mathrm{N}=605)$ & $3.04(1.49)$ & $78.7 \%$ & $21.3 \%$ & $0 \%$ \\
\hline & Caregivers $(\mathrm{N}=329)$ & $3.64(1.59)$ & $79.6 \%$ & $7.0 \%$ & $13.4 \%$ \\
\hline \multirow{3}{*}{$\begin{array}{l}\text { Conduct } \\
\text { problems } \\
(0-10)\end{array}$} & $\mathrm{LBC}(\mathrm{N}=445)$ & $1.87(1.92)$ & $81.6 \%$ & $1.9 \%$ & $6.5 \%$ \\
\hline & Non-LBC $(\mathrm{N}=607)$ & $1.68(1.43)$ & $87.7 \%$ & $7.1 \%$ & $5.1 \%$ \\
\hline & Caregivers $(\mathrm{N}=333)$ & $1.44(1.59)$ & $88.6 \%$ & $4.1 \%$ & $6.9 \%$ \\
\hline \multirow{3}{*}{$\begin{array}{l}\text { Peer Problems } \\
\qquad(0-10)\end{array}$} & $\mathrm{LBC}(\mathrm{N}=440)$ & $3.48(1.65)$ & $88.4 \%$ & $6.4 \%$ & $5.2 \%$ \\
\hline & Non-LBC $(\mathrm{N}=601)$ & $2.93(1.35)$ & $87.5 \%$ & $9.5 \%$ & $3.0 \%$ \\
\hline & Caregivers $(\mathrm{N}=331)$ & $3.03(1.56)$ & $84.0 \%$ & $12.7 \%$ & $3.3 \%$ \\
\hline \multirow{3}{*}{$\begin{array}{c}\text { Total } \\
\text { difficulties } \\
(0-40)\end{array}$} & $\mathrm{LBC}(\mathrm{N}=413)$ & $12.55(5.96)$ & $81.1 \%$ & $17.4 \%$ & $1.5 \%$ \\
\hline & Non-LBC $(\mathrm{N}=547)$ & $10.17(3.38)$ & $82.3 \%$ & $16.5 \%$ & $1.8 \%$ \\
\hline & Caregivers $(\mathrm{N}=292)$ & $11.12(5.14)$ & $84.9 \%$ & $11.3 \%$ & $3.8 \%$ \\
\hline \multirow{3}{*}{$\begin{array}{c}\text { Prosocial } \\
\text { behavior } \\
(10-0)\end{array}$} & LBC $(\mathrm{N}=469)$ & $7.14(1.90)$ & $81.8 \%$ & $13.6 \%$ & $4.7 \%$ \\
\hline & Non-LBC $(\mathrm{N}=650)$ & $7.09(1.96)$ & $78.5 \%$ & $17.7 \%$ & $3.9 \%$ \\
\hline & Caregivers $(\mathrm{N}=337)$ & $10.0(7.22)$ & $97.6 \%$ & $2.4 \%$ & $0 \%$ \\
\hline
\end{tabular}

Note: LBC-Left-behind children; Non-LBC-Non-Left behind children.

Table 3. Comparison of mental health of children of migrant parents with those living with their parents.

\begin{tabular}{|c|c|c|c|c|}
\hline \multicolumn{2}{|c|}{ Groups of children } & \multirow{2}{*}{$\frac{\mathrm{N}}{447}$} & \multirow{2}{*}{$\begin{array}{l}\text { Mean (SD) } \\
3.31(1.94)\end{array}$} & \multirow[t]{2}{*}{ Sig. } \\
\hline \multirow{3}{*}{ Hyperactivity } & LBC & & & \\
\hline & & & & \multirow{2}{*}{$\mathrm{t}(1055)=7.849, p=0.00$} \\
\hline & Non-LBC & 610 & $2.56(1.11)$ & \\
\hline \multirow{2}{*}{ Emotional problems } & LBC & 443 & $3.93(2.40)$ & \multirow{2}{*}{$\mathrm{t}(1046)=7.310, p=0.00$} \\
\hline & Non-LBC & 605 & $3.04(1.49)$ & \\
\hline \multirow{2}{*}{ Conduct problems } & LBC & 445 & $1.87(1.92)$ & \multirow{2}{*}{$\mathrm{t}(1050)=1.899, p=0.04$} \\
\hline & Non-LBC & 607 & $1.68(1.43)$ & \\
\hline \multirow{3}{*}{ Peer problems } & LBC & 440 & $3.48(1.65)$ & \multirow{3}{*}{$\mathrm{t}(1039)=5.833, p=0.00$} \\
\hline & & & & \\
\hline & Non-LBC & 601 & $2.93(1.35)$ & \\
\hline \multirow{3}{*}{ Total difficulties } & LBC & 413 & $12.55(5.96)$ & \multirow{3}{*}{$\mathrm{t}(958)=7.828, p=0.00$} \\
\hline & & & & \\
\hline & Non-LBC & 547 & $10.17(3.38)$ & \\
\hline \multirow{3}{*}{ Prosocial behavior } & LBC & 450 & $7.14(1.90)$ & \multirow{3}{*}{$\mathrm{t}(1070)=0.368, p=0.71$} \\
\hline & & & & \\
\hline & Non-LBC & 622 & $7.09(1.96)$ & \\
\hline
\end{tabular}

Note: LBC-Left-behind children; Non-LBC-Non-Left behind children. 
There is a statistically significant difference between the two groups, $\mathrm{t}(958)=$ $7828, p=0.00$.

In terms of each aspect of mental health, we found a difference in a trend that children of migrant parents were face with more difficulties than those living with parents. Specifically, children whose parents work away from home had higher scores of hyperactivity than those living with parents, the mean scores of these two groups were 3.31 for the former and 2.56 for the latter and $t(1046)=$ $7.310, p=0.00$. For emotional problems, the mean scores of these two groups, respectively, were 3.93 and $3.04, \mathrm{t}(1055)=7.849, p=0.00$; for conduct problems, 1.87 and 1.68, $\mathrm{t}(1050)=1.899, p=0.00$ for behaviour problems; and $\mathrm{t}(1039)=$ 5.833, $p=0.000$ for peer problems.

It is noted that there was no difference between these 2 children groups in scores of prosocial problems $(t(1070)=0.368, p=0.71)$.

\subsection{Comparison of Mental Health of Children of Migrant Parents}

In terms of gender, there is no difference in total difficulties score between girls and boys. However, considering each aspect we found that girls were faced with more emotional problems than boys, the average score they achieved is 4.36 and it is 3.47 for boys and the statistically significant difference was $\mathrm{t}(441)=3.929, p$ $=0.00$; while boys had more conduct problems than girls (the average score is 2.08 and 1.68 , respectively and $\mathrm{t}(443)=2.195, p=0.02$. The group of girls having parents working away from home also reported a higher score of prosocial behavior than those of boy group with the average score of 7.36 and 6.91, respectively, $\mathrm{t}(448)=2.527, p=0.01)$.

Children aged 12 - 15 reported a higher score of hyperactivity/inattention problems than those aged $9-11$, the average score is 3.57 and 3.03, respectively and $t(443)=2.916, p=0.00$. There is no statistical difference in remaining aspects of mental health between groups of children having migrant parents.

In terms of migration time, there is a difference in the total difficulties score between groups of children having parents working away from home $\mathrm{F}(319)=$ 5.408, $p=0.005$. Particularly, children whose parents worked away from home for less than 2 years reported higher total difficulties score than those having absent parents for from 2 to 5 years (the average difference score between two groups was 2.44; $p=0.001$ ). Considering each aspect of the difficulty, on notable point is that there is difference between those children groups in hyperactivity, $\mathrm{F}(341)=5.921, p=0.003$, in which children of parents working away from home for less than 2 years reported higher score in hyperactivity problems than those having parents working away for 2 - 5 years (the average score of difference between two groups was $0.84, p=00.1$ ); conduct problems $\mathrm{F}(339)=10.396, p=$ 0.000 , in which children whose parents working away from home for less than two years had higher score in conduct problems than those having parents working away for 2 - 5 years (the average score of difference between 2 groups was $1.00, p=0.00$ ). However, there is no statistical difference in aspects of emotional problems, $\mathrm{F}(338)=2.412, p=0.09$; peer problems $\mathrm{F}(335)=2.645, p=$ 
0.07. It is also noted that there is a difference in these children groups in terms of prosocial behaviour, $\mathrm{F}(342)=7.788, p=0.00$.

The data in Table 4 shows that there is a difference in the total difficulties score between groups of children whose parents migrate for employment $(\mathrm{F}(397)=4.743, p=0.00)$. Considering every aspect, there is a statistically significant difference in hyperactivity problems between these children groups $\mathrm{F}(429)=3.699, p=0.02$, in which the group of children with both parents working far away from home reported higher score of hyperactivity problems than those having migrant father (the average difference score is $0.56, p=0.00$ ); emotional problem $\mathrm{F}(424)=4.124, p=0.01$, in which the group children whose both parents work away from home reported higher scores of emotional problems than those with only fathers migrating for employment (the average difference score between 2 groups is $0.71, p=0.00$ ).

In terms of residential area of surveyed participants, one notable point is that there is statistical significance in the total difficulties scores in children whose parents work away from home $(\mathrm{F}(412)=12.709, p=0.00)$. Considering each aspect, we found that there is statistical significance difference between children groups in hyperactivity problems $(\mathrm{F}(446)=11.380, p=0.00)$. Children group in Phu Tho province reported a higher score of hyperactivity problems than those in Bac Ninh province (the average difference score between two groups is 0.66 ,

Table 4. Comparison of mental health of LBC $(\mathrm{N}=464)$.

\begin{tabular}{|c|c|c|c|c|c|c|c|}
\hline \multirow[t]{2}{*}{ Criteria } & \multirow[t]{2}{*}{ Classification } & Hyperactivity & $\begin{array}{c}\text { Emotional } \\
\text { problems }\end{array}$ & $\begin{array}{l}\text { Conduct } \\
\text { problems }\end{array}$ & $\begin{array}{c}\text { Peer } \\
\text { problems }\end{array}$ & $\begin{array}{c}\text { Total } \\
\text { difficulties }\end{array}$ & $\begin{array}{l}\text { Prosocial } \\
\text { behavior }\end{array}$ \\
\hline & & \multicolumn{6}{|c|}{ Mean (SD) } \\
\hline \multirow{2}{*}{ 1. Sex } & Male & 3.39 (1.97) & $3.47(2.21)$ & $2.08(2.11)$ & $3.45(1.77)$ & $12.36(6.09)$ & $6.91(1.99)$ \\
\hline & Female & $2.23(1.90)$ & $4.36(2.50)^{\star \star \star}$ & $1.68(1.71)^{\star}$ & $3.50(1.51)$ & $12.73(5.84)$ & $7.36(1.78)^{\star \star}$ \\
\hline \multirow{2}{*}{ 2. Age } & $9-11$ years old & 3.03 (1.93) & $3.83(2.42)$ & $1.71(1.96)$ & $3.46(1.96)$ & $11.90(6.00)$ & $7.08(1.96)$ \\
\hline & 12 - 15 years old & $3.57(1.91)^{\star * *}$ & $4.01(2.39)$ & $2.03(1.88)$ & $3.49(1.57)$ & $13.14(5.88)$ & $7.20(1.85)$ \\
\hline \multirow{3}{*}{$\begin{array}{l}\text { 3. Length } \\
\text { of parental } \\
\text { migration }\end{array}$} & $\leq 2$ years & $3.71(1.97)$ & $3.85(2.27)$ & $2.14(2.00)$ & $3.60(1.65)$ & $13.22(5.98)$ & $6.80(1.92)$ \\
\hline & 2 - 5 years & $2.87(1.81)$ & $3.50(2.21)$ & $1.14(1.43)$ & $3.20(1.39)$ & $10.78(5.00)$ & $7.62(1.60)$ \\
\hline & $>5$ years & $3.20(2.05)^{\star \star \star}$ & $4.23(2.70)$ & $4.23(2.70)^{\star * *}$ & $3.19(1.64)$ & $12.37(6.09)^{\star * *}$ & $7.52(1.77)^{\star * \star}$ \\
\hline \multirow{3}{*}{$\begin{array}{l}\text { 4. Who work } \\
\text { far away } \\
\text { from home }\end{array}$} & Father & $2.99(1.98)$ & $3.52(2.35)$ & $1.63(1.78)$ & $3.28(1.72)$ & $11.38(5.86)$ & $7.28(1.83)$ \\
\hline & Mother & $3.41(1.94)$ & $4.13(2.33)$ & $2.19(2.16)$ & $3.71(1.52)$ & $13.41(6.09)$ & $7.18(1.96)$ \\
\hline & Two parents & $3.55(1.88)^{\star}$ & $4.24(2.45)^{\star \star}$ & $1.88(1.82)$ & $2.37(1.63)$ & $13.08(5.74)^{\star * \star}$ & $7.01(1.88)$ \\
\hline \multirow{3}{*}{$\begin{array}{l}\text { 5. Children's } \\
\text { residential area }\end{array}$} & Phu Tho & $3.39(1.95)$ & $4.20(2.37)$ & $1.68(1.70)$ & $3.42(1.53)$ & $12.85(5.72)$ & $7.66(1.64)$ \\
\hline & Bac Ninh & $2.73(1.83)$ & $3.28(2.35)$ & $1.43(1.83)$ & $3.28(1.53)$ & $10.56(5.68)$ & $17.37(1.94)$ \\
\hline & Ha Nam & $3.71(1.90)^{\star * *}$ & $4.26(2.36)^{\star \star \star}$ & $2.32(2.02)^{\star * *}$ & $3.66(1.78)$ & $13.88(5.92)^{\star * *}$ & $6.67(1.90)^{\star * *}$ \\
\hline 6. The frequency of & Less frequent & $3.37(1.91)$ & $4.05(2.42)$ & $1.85(1.94)$ & $3.56(1.65)$ & $12.87(5.98)$ & $7.22(1.84)$ \\
\hline children and parents & Frequent & $3.21(1.98)$ & $3.75(2.36)$ & $1.87(1.87)$ & $3.36(1.63)$ & $12.11(5.92)$ & $7.06(1.97)$ \\
\hline
\end{tabular}

Note: Significance level ${ }^{\star}-p<0.05 ;{ }^{* *}-p<0.01 ;{ }^{\star * *}-p<0.001$. 
$p=0.00)$. Emotional problems: $\mathrm{F}(442)=7.904, p=0.00$, children group in Phu Tho also reported a higher score of emotional problems than those in Bac Ninh (the average difference score between two groups is $0.91, p=0.00$ ). Conduct problems: $\mathrm{F}(444)=9.879, p=0.00$, children group in Ha Nam province reported a higher score of conduct problems than those in Phu Tho (the average difference score between two groups $=0.63, p=0.00$ ). The data in Table 4 also indicates a statistical significance difference in prosocial problems between children groups in different localities $\mathrm{F}(449)=11.478, p=0.00$, in which there is a difference between children groups in Phu Tho and Ha Nam (the average difference score between two groups is $0.99, p=0.00$ ).

The results in the Table 4 also reveal that in terms of parent-children relationship, there is no statistical significance in expression of difficulties of children having migrant parents.

\subsection{Some Factors Predicting the Total Difficulties of LBC}

One of our research questions is which individual and family factors could anticipate the children's total difficulties?

In order to model the impact on children's total difficulties, an analysis of multiple linear regression was carried out by establishing Enter's models (at the same time putting the variables into the model). Multiple linear regression model is as follows:

$$
Y_{t . d}=\beta_{0}+\beta_{1}\left(X_{i}\right)+\beta_{2}\left(X_{2}\right)+\ldots \beta_{k}\left(X_{k}\right)
$$

where " $Y_{t . d}$ "-is the indicator of children's total difficulties; " $\beta_{0}$ " -is a constant;

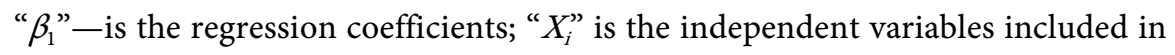
the model; " $k$ " is independent variables of the model.

We set up the regression model with two variable groups at individual and family levels: Model 1 includes only independent variables belonging to personal characteristics of children, specifically including age; self-esteem; educational stages/level of school; self-assessment of academic performance; self-assessment of life success. Model 2 has the variables which had been included in the Model 1 and additional independent variables of the children's family, inclusive of the number of siblings living with them; length of parental migration; father or mother who works away from home; frequency of parents' visits and frequency of communication between children and their parents. In total, 5 variables under the group of children's personal characteristics and 5 variables of family group were analyzed in the models. Prior to the multiple linear regression, checking for assumption violations was carried out which indicated that the assumptions was basically met.

Application of multiple linear regression analysis has provided us the following results (Table 5).

Testing of the appropriateness of the model showed that the F-statistic in both models was at a very high significance level $(p<0.001)$. Therefore, it can be confirmed that the database is appropriate for these two models. In Model 1, 5 va- 
Table 5. Linear regression model predicting the total difficulties of LBC.

\begin{tabular}{lcc}
\hline \multicolumn{1}{c}{ Independent Variables } & Model 1 & Model 2 \\
\hline \multicolumn{1}{c}{$\mathrm{R}^{2}$} & 0.266 & 0.283 \\
$\mathrm{R}$ adjusted & 0.251 & 0.253 \\
& $17.826^{* * *}$ & $9.523^{* * *}$ \\
& $-0.337^{* * *}$ & $-0.322^{\star * *}$ \\
1. Self-esteem & -0.233 & -0.222 \\
2. Ages & 0.294 & 0.278 \\
3. Level of school & $-0.260^{\star * *}$ & $-0.268^{\star * *}$ \\
4. Self-assessment of academic performance (score scale 1 - 5) & -0.046 & -0.100 \\
5. Self-assessment of success in life (score scale 1 - 5) & & -0.033 \\
6. No. of siblings whom children living with & & -0.043 \\
7. Length of parental migration & & $0.115^{\star}$ \\
8. Father or mother working away from home & & 0.090 \\
9. Frequency of parents' visit & & 0.026 \\
10. Frequency of communication between parents and children & & \\
\hline
\end{tabular}

Note: Significance level ${ }^{*}-p<0.05{ }^{* *}-p<0.01{ }^{* * *}-p<0.001$.

riables of children's individual characteristics can explain $26.6 \%$ of variation of indicators of total difficulties in children with migrant parents. In Model 2, when the variable group of family factors ( 5 variables) is added, the adjusted Rsquared increased to $28.3 \%$ compared with Model 1 which means that the addition of independent variables of children's family factors in Model 2 strengthen the explanation for the influence of the independent variables to the total difficulties of children of migrant parents.

Testing statistical assumption for regression coefficients in the models reveals that some hypotheses of this research on the effects of variables is confirmed ( $\beta$ $\neq 0$ ). However, the number of variables that can affect the statistical significance in each model is the same in these models, 2 variables in Model 1 and 3 variables in Model 2. We believe that children's self-assessment of their school performance and self-esteem is the key factor affecting their total difficulties. It means that, if left-behind children's self-esteem and success in their school performance can reduces the total difficulties of left-behind children in this study.

\section{Discussions}

If parental migration, for such as going to a city or working abroad for employment opportunities is considered as a livelihood strategy that helps rural workers get a job and improve their families' living conditions, a potential cost for the psychological well-being of these families' children due to their separation from parents needs to be taken into account [13]. The study of the psychological well-being of children with parents working away from home in Northern Vietnam is one of the first studies on separation between children and their absent parents. The self-report and caregiver-report SDQ versions were used in this 
study. Results of a number of previous studies on the impact of parental migration for employment on children's psychological well-being remain very different.

Comparing the results of our study with that of a research by Amstadter et al. with 1368 adolescents in two Central Vietnam provinces of Da Nang and Khanh Hoa, using the same SDQ scale, the mean scores of this study is higher $(15.1 \%$ as rated by parents, compared to 9.1\%) [16]; This percentage is also higher than that in a study by Dang Hoang Minh et al. (2013) carried out with 1314 parents of children aged 6 - 16 years, $15.1 \%$ compared to $13.18 \%$ [15]. This is lower than that of Ngo Thanh Hoi et al. who also used the SDQ scale in children aged 10 16 years in some urban districts in Hanoi (19.46\%). However, overall, our research results fall in the range of $10 \%$ to $20 \%$ which is the threshold of mental health problems in Asian children (cited according to [15]).

The compared total difficulties score reported by children having parents working away from home in our study is higher than that of children in a study of Dang Hoang Minh et al. who also used a SDQ scale for 591 adolescents $(18.9 \%$ vs. $10.73 \%$ ). The reason for this difference is that we carried out surveys with children of migrant parents in only three provinces, while the study by Dang Hoang Minh et al. were implemented at 60 sites in 10 representative provinces of Vietnam.

Research by Graham et al. (2011) showed that there was no difference in the psychological well-being of Vietnamese children of migrant parents and children of non-migrant parents [13]. Conversely, research by Nguyen Viet Cuong (2015) showed that, lack of long-term parental care caused nutrition, psychological well-being and school problems in the children with parents migrating [14]. Our study demonstrated that children of migrant parents had a higher total difficulties score than that of children with non-migrant parents (Table 4). In addition, the psychological well-being problems tend to increase in children whose mothers or both parents migrating for employment.

Parents working away from home (in city or abroad) and leaving their children to their relatives (grandparents in mother's or father's side) mean a separation event to these left-behind children. According to scholars of attachment theory, the insecurity and distance of these children with their caregivers since childhood is one the factors which are able to predict psychological well-being problems such as anxiety, depression, hyperactivity and behaviour disorders [17]. Researches by authors in the field of mental health also revealed the same results. The separating children from their parents for various reasons are likely to affect their psychological well-being [18] [19].

In Northern Vietnam, with the heavy influence of Confucianism, women in the family are involved in housework, caring and educating their children [20] [21]. When a woman leaves home to work in the city or abroad, her partner has to take responsibility for every housework and child care. As a result, the husband plays two roles of either earning money or doing housework and childcare, which makes him stressed. Rapid changes in men's roles in families having their 
wives working away from home can lead to violent reactions, including violence against family members [22]. Children are able to become victims for men to give vent to their frustrations and tensions due to their separation from wives and their dual role in the families. This partially explains a higher total difficulties score in children of mothers migrating for employment than those of fathers in the same situation.

In this study, the proportion of children of migrant parents under borderline and abnormal categories is higher than that of children living with their parents. In order to confirm this, further research on this topic is needed for other children's groups since our study was conducted in three residential areas having a higher number of export workers than other areas in Northern Vietnam. Children left behind in a community where many parents are away for employment do not showed more psychological health problems than children living with their parents. Graham and his colleagues pointed out that left-behind children in the Philippines did not have more psychological health problems than children living with their parents. When there are many children left in the community, they themselves will feel that they are not the exception or different from the others, jealousy and ridicule between children do not occur. It is also a factor protecting children from many psychological health problems [13].

\section{Conclusions}

According to SDQ score scale, the proportion of children of migrant parents under borderline and abnormal categories is higher than that of children living with their parents and also higher than other children groups in some studies in Vietnam.

Comparison between LBC and Non-LBC groups indicated a statistically significant difference in the total difficulties score between the two groups and each aspect of the psychological well-being.

Self-esteem and self-assessment of academic performance is the key factors affecting total difficulties of left-behind children. It means that, if left-behind children's self-esteem and success in their school performance increases, the total difficulties of these children can be reduced.

The results of the study show that parental migration due to employment have a negative influence on their children's psychological well-being. Therefore, further research on this issue is needed so that solutions are available to soften negative impacts of parental migration for employment on their children.

\section{Acknowledgements}

This research is funded by Vietnam National University, Hanoi (VNU) under project number QG.15.43.

\section{References}

[1] Zhao, Q., Yu, X., Wang, X. and Glauben, T. (2014) The Impact of Parent Migration on Children's School Performance in Rural China. China Economic Review, 31, $43-$ 54. https://doi.org/10.1016/j.chieco.2014.07.013 
[2] Jia, Z. and Tian, W. (2010) Health-Related Quality of Life of "Left-Behind Children": A Cross-Sectional Survey in Rural China. Quality of Life Research, 19, 775780. https://doi.org/10.1007/s11136-010-9638-0

[3] Luo, J., Gao, W. and Zhang, J. (2011) The Influence of School Relationship on Anxiety and Depression among Chinese Adolescents Whose Parents Are Absent. Social Behavior and Personality, 39, 289-298. https://doi.org/10.2224/sbp.2011.39.3.289

[4] Ye, J.Z. and Pan, L. (2011) Differentiated Childhoods: Impacts of Rural Labor Migration on Left-Behind Children in China. The Journal of Peasant Studies, 38, 355-377. https://doi.org/10.1080/03066150.2011.559012

[5] Fan, F., Su, L. and Gill, M. (2010) Emotional and Behavior Problems of Chinese Left-Behind Children: A Preliminary Study. Social Psychiatry and Psychiatry Epidenmiology, 45, 655-664. https://doi.org/10.1007/s00127-009-0107-4

[6] Shen, G.C. and Shen, S.J. (2014) Study on the Psychological Problems of Left-Behind Children in Rural Areas and Countermeasures. Studies in Sociology of Science, 5, 59-63.

[7] Sun, X.J., et al. (2015) Psychological Development and Educational Problems of Left-Behind Children in Rural China. School Psychology International, 36, 227-252. https://doi.org/10.1177/0143034314566669

[8] Wen, M. and Lin, D. (2012) Child Development in Rural China: Children Left Behind by Their Migrant Parents and Children of Nonmigrant Families. Child Development, 83, 120-136. https://doi.org/10.1111/j.1467-8624.2011.01698.x

[9] General Statistics Office Vietnam (2016) Report on Labour Force Survey 2015: General Statistics Office Vietnam, 46-47.

[10] Thinh, H.B. (2012) Research on Gender and Migration in Vietnam: An Analysis Overview. In: Xoan, N.T.H., Ed., Gender and Migration: Asia Vision, Vietnam National University, Hochiminh City, 12-31.

[11] Piper, N. (2012) Gender and Migration in ASEAN. In: Xoan, N.T.H., Ed., Gender and Migration: Asia Vision, Vietnam National University, Hochiminh City, 32-51.

[12] Binh, V.N. (2012) Legal Issues, Policies and Practices of Women Going Overseas Labor from the Perspective of Rights and Gender. In: Xoan, N.T.H., Ed., Gender and Migration: Asia Vision, Vietnam National University, Hochiminh City, 71-100.

[13] Graham, E. and Jordan, L.P. (2011) Migrant Parents and the Psychological WellBeing of Left-Behind Children in Southeast Asia. Journal of Marriage and Family, 74, 763-787. https://doi.org/10.1111/j.1741-3737.2011.00844.x

[14] Nguyen, C.V. (2016) Does Parental Migration Really Benefit Left-Behind Children? Comparative Evidence from Ethiopia, India, Peru and Vietnam. Social Science \& Medicine, 153, 230-239.

[15] Đặng, H.M., Weiss, B. and Nguyễn, C.M. (2013) Sức khỏe tâm thần trẻ em Việt Nam: Thực trạng và các yếu tố nguy cơ [Results of the First Nationally Representative Child Mental Health Epidemiological and Risk Factor Assessment in Vietnam]. Vietnamese National University Press, Hanoi, Vietnam, 42-43.

[16] Amstadter, A.B., et al. (2011) Prevalence and Correlates of Probable Adolescent Mental Health Problems Reported by Parents in Vietnam. Social Psychiatry and Psychiatric Epidemiology, 46, 95-100. https://doi.org/10.1007/s00127-009-0172-8

[17] Lee, A. and Hankin, B.L. (2009) Insecure Attachment, Dysfunctional Attitudes, and Low Self-Esteem Predicting Prospective Symptoms of Depression and Anxiety during Adolescence. Journal of Clinical Child \& Adolescent Psychology, 38, 219-231. https://doi.org/10.1080/15374410802698396 
[18] Amato, P.R. and Cheadle, J. (2005) The Long Reach of Divorce: Divorce and Child Well-Being across Three Generations. Journal of Marriage and Family, 67, 191-206. https://doi.org/10.1111/j.0022-2445.2005.00014.x

[19] Huurre, T., Junkkari, H. and Aro, H. (2006) Long-Term Psychosocial Effects of Parental Divorce. European Archives of Psychiatry and Clinical Neuroscience, 256, 256-263. https://doi.org/10.1007/s00406-006-0641-y

[20] Hiền, P.T.T. (2014) Đạo đức gia đình trong pháp luật phong kiến Việt Nam. Tạp chí khoa học xã hội Việt Nam số, 5, 28-36.

[21] Thêm, T.N. (2006) Tìm về bản sắc văn hóa Việt Nam. NXB Thành Phố Hồ Chí Minh, 514-518.

[22] Krishnan, S., Rocca, C.H., Hubbard, A.E., Subbiah, K., Edmeades, J. and Padian, N.S. (2010) Do Changes in Spousal Employment Status Lead to Domestic Violence? Insights from a Prospective Study in Bangalore, India. Social Science \& Medicine, 70, 136-143. https://doi.org/10.1016/j.socscimed.2009.09.026

Submit or recommend next manuscript to SCIRP and we will provide best service for you:

Accepting pre-submission inquiries through Email, Facebook, LinkedIn, Twitter, etc. A wide selection of journals (inclusive of 9 subjects, more than 200 journals)

Providing 24-hour high-quality service

User-friendly online submission system

Fair and swift peer-review system

Efficient typesetting and proofreading procedure

Display of the result of downloads and visits, as well as the number of cited articles

Maximum dissemination of your research work

Submit your manuscript at: http://papersubmission.scirp.org/

Or contact jss@scirp.org 